\title{
PRAKTIK AKAD WADI'AH YAD DHAMANAH PADA PRODUK TABUNGAN DI BANK BRI SYARIAH KANTOR CABANG PURWOKERTO
}

\author{
Widya Dwi Pratiwi ${ }^{1}$, Makhrus ${ }^{2}$ \\ 1Universitas Muhammadiyah Purwokerto, Email : widyadwipratiwi0708@gmail.com \\ 2Universitas Muhammadiyah Purwokerto, Email : makhrus.ahmadi@gmail.com
}

\begin{abstract}
ABSTRAK
Wadi'ah merupakan salah satu akad yang digunakan dalam perbankan syariah dalam mengelola produk penghimpunan dana seperti produk tabungan. Tabungan sendiri merupakan jenis simpanan yang sudah terkenal baik dikalangan pedesaan sampai perkotaan. Penelitian ini bertujuan untuk mengetahui produk tabungan apa saja yang menggunakan akad wadi'ah yad dhamanah di Bank Rakyat Indonesia Syariah Kantor Cabang Purwokerto serta mengetahui kesesuaian antara dasar hukum tentang pengelolaan tabungan wadi'ah yang sudah ada di Fatwa Dewan Syariah Nasional Majelis Ulama Indonesia (selanjutnya disingkat DSN-MUI) dengan praktik dilapangan yang sesungguhnya oleh pegawai-pegawai bank syariah itu sendiri. Penelitian ini menggunakan metode kualitatif dengan pendekatan yuridis normatif dengan pengumpulan data menggunakan teknik observasi, wawancara dan dokumentasi. Sumber datanya bersumber dari brosur, formulir pembukaan rekening. Analisis datanya dengan cara mengolah data yang di dapat saat observasi dan wawancara kemudian dianalis dan disesuaikan dengan Fatwa Dewan Syariah Nasional Majelis Ulama Indonesia DSN-MUI. Dalam melakukan kegiatan operasionalnya BRI Syariah Kantor Cabang Purwokerto mempunyai 4 kantor cabang pembantu antara lain Kantor Cabang Pembantu Ajibarang, Kantor Cabang Pembantu Purbalingga, Kantor Cabang Pembantu Kebumen dan Kantor Cabang Pembantu Cilacap. Hasil penelitian ini menunjukan bahwa penerapan akad wadi'ah di BRI Syariah Kantor Cabang Purwokerto berdasar pada fatwa yang dikeluarkan oleh Dewan Syariah Nasional Majelis Ulama Indonesia (DSN-MUI) yang telah memenuhi ketentuan umum tabungan wadi'ah yaitu seperti bersifat simpanan, simpanan bisa diambil kapan saja (on call) atau berdasarkan kesepakatan dan tidak ada imbalan yang disyaratkan, kecuali dalam bentuk pemberian ('athaya). Dalam melakukan penerapan tabungan yang menggunakan akad wadi'ah di BRI Syariah Kantor Cabang Purwokerto juga sudah sesuai dengan rukun dan syarat akad.
\end{abstract}

Kata-kata kunci : Wadi'ah, Akad, Tabungan

\section{ABSTRACT}

Wadi'ah is one of the contracts used in Islamic banking in managing funds collection products such as savings products. Savings alone is a type of savings that has been well-known among the rural to 
urban areas. This study aims to find out what savings products are using the wadi'ah yad dhamanah agreement at the Bank Rakyat Indonesia Syariah Purwokerto Branch Office and to find out the compatibility between the legal basis of the management of existing wadi'ah savings in the Fatwa of the National Sharia Council of the Indonesian Ulema Council (hereinafter abbreviated as DSN-MUI) with practice in the real field by Islamic bank employees themselves. This study uses a qualitative method with a normative juridical approach by collecting data using observation, interview and documentation techniques. The data source comes from brochures, account opening forms. Analysis of the data by processing data obtained during observation and interviews and then analyzed and adjusted to the Fatwa of the National Sharia Council of the Indonesian Ulema Council DSN-MUI. In conducting its operational activities, BRI Syariah Purwokerto Branch Office has 4 sub-branch offices including Ajibarang Sub-Branch Office, Purbalingga Sub-Branch Office, Kebumen Sub-Branch Office and Cilacap Sub-Branch Office. The results of this study indicate that the application of the wadi'ah contract in the BRI Syariah Branch Office of Purwokerto is based on the fatwa issued by the National Sharia Council of the Indonesian Ulama Council (DSN-MUI) which has fulfilled the general provisions of wadi'ah savings, such as deposits, deposits can be taken at any time (on call) or based on an agreement and no compensation required, except in the form of giving ('athaya). In implementing savings, using the wadi'ah contract at the BRI Syariah Purwokerto Branch Office is also in accordance with the pillars and terms of the contract.

Keywords: Wadi'ah, Akad, Savings

\section{PENDAHULUAN}

Lembaga keuangan merupakan sesuatu yang tidak dapat dipisahkan dari perekonomian masyarakat. Dengan adanya lembaga keuangan sangat membantu karena di dalamnya terjadi suatu penghimpunan dana dari masyarakat, kemudian dana tersebut kembali disalurkan kepada masyarakat dalam bentuk pembiayaan. Di Indonesia lembaga keuangan mengalami perkembangan yang pesat yang menunjukkan peran dan kontribusi pengelolaan dana phak ketiga secara optimal yang ditandai dengan perkembangan signifikan aset, pasar, dan kesadaran masyarakat untuk bertransaksi secara syariah (Makhrus, 2015: 53-54). Bank bersifat syariah atau biasa disebut bank syariah merupakan bank yang dalam kegiatan operasional dan produk yang dikembangkan berlandaskan pada Al-Qur'an dan Hadits. Bank syariah berani menggunakan label syariah berarti bank syariah harus mengacu pada ketentuan syariah, sebagai konsekuensinya bank syariah harus menggunakan pedoman-pedoman yang secara legal formal disepakati sebagai pedoman bank syariah, yaitu Fatwa Dewan Syariah Nasional Majelis Ulama Indonesia (selanjutnya disingkat DSN-MUI). Usaha pokok bank syariah adalah memberikan 
pembiayaan dan jasa-jasa dalam lalu lintas pembayaran serta peredaran uang yang pengoperasiannya sesuai dengan prinsip syariah.

Perkembangan bank syariah juga didukung dengan dikeluarkannya regulasi untuk perbankan syariah oleh Bank Indonesia yang telah diatur dalam undang-undang, yaitu Undang-undang Nomor 21 Tahun 2008 tentang Perbankan Syariah. Tujuan utama pendirian perbankan syariah sebagai upaya kaum muslimin untuk mendasari segenap aspek kehidupan ekonominya yang berlandaskan Al-qur'an dan Hadits. Namun demikian, fenomena ini tidak dibarengi dengan kualitas bank syariah itu sendiri. Banyak produk-produk bank syariah yang dianggap sebagian masyarakat belum memenuhi prinsip-prinsip syariah.

Salah satu bank syariah di Indonesia adalah Bank BRI Syariah yang telah beroperasi sejak tanggal 17 November 2008 dan terpisah dengan BRI konvensional. Untuk produk penghimpunan dana di BRI Syariah salah satunya adalah dengan tabungan. Menabung merupakan tindakan yang dianjurkan dalam Islam, karena dengan menabung seseorang muslim mempersiapkan diri untuk pelaksanaan perencanaan di masa yang akan datang sekaligus untuk menghadapi hal-hal yang tidak diinginkan. Dalam Al-qur'an juga terdapat ayat yang menjelaskan tentang diperintahkannya kaum muslimin untuk mempersiapkan hari esok yang lebih baik. Adanya peluang ini BRI Syariah kemudian mengeluarkan berbagai macam produk tabungan yang pengelolaannya berdasarkan syariat Islam dengan menggunakan akad mudharabah dan akad wadi'ah.

Akad mudharabah atau bagi hasil ini sifatnya investasi diperuntukan untuk masyarakat yang ingin mendapatkan keuntungan dalam menabung atau dalam istilah lain kerja sama antara pihak bank dan nasabah, dimana pihak bank boleh memanfaatkan dana yang dititipkan nasabah, kemudian adanya bagi hasil antara pihak bank dan nasabah berdasarkan perjanjian di awal yang telah di sepakati bersama, karena bersifat investasi simpanan tersebut tidak dapat di ambil kapan saja melainkan berdasarkan kesepakatan bersama. Sedangkan wadi'ah merupakan jenis simpanan dimana nasabah dapat mengambil dananya kapan saja meskipun pihak bank boleh memanfaatkan dana tersebut. Tidak adanya bagi hasil akan tetapi pihak bank dapat memberikan bonus kepada nasabah serta 
pemberian bonus tersebut tidak diperjanjikan di awal akad. Dari kedua tabungan tersebut yang banyak di minati adalah tabungan yang menggunakan akad wadi'ah karena selain dana yang tersimpan aman simpanan juga bisa di ambil kapan saja.

Tabungan wadi'ah secara umum ada dua macam yaitu wadi'ah yad amanah dan wadi'ah yad dhamanah. Namun di BRI Syariah Kantor Cabang Purwokerto untuk tabungan yang menggunakan akad wadi'ah lebih tepatnya menggunakan akad wadi'ah yad dhamanah tidak ada produk yang menggunakan akad wadi'ah yad amanah. Karena pihak bank dapat memanfaatkan dan menggunakan titipan tersebut, sehingga semua keuntungan yang dihasilkan dari dana titipan tersebut menjadi milik bank (demikian bank juga sebagai penanggung seluruh kerugian). Sebagai imbalan si penitip akan mendapat jaminan keamanan terhadap titipannya. Meskipun demikian pihak penerima titipan atau bank tidak dilarang untuk memberikan semacam bonus dengan catatan tidak ditetapkan dalam bentuk nominal melainkan dalam bentuk barang/jasa. Bonus yang diberikan berdasarkan kebijakan dari bank BRI Syariah Kantor Cabang Purwokerto. Produk penghimpunan dana di BRI Syariah yang paling di minati nasabah adalah produk tabungannya, khususnya tabungan Faedah BRI Syariah iB. Tabungan Faedah BRI Syariah iB adalah tabungan umum diperuntukan untuk yang sudah berusia 17 tahun keatas. Dengan fasilitas yang serba mudah membuat produk tabungan ini di minati oleh nasabah. Pihak Bank BRI Syariah Kantor Cabang Purwokerto juga dapat memberikan bonus kepada nasabah secara sukarela (Adhitya, 9//2018).

Bonus diberikan kepada nasabah sebagai upaya merangsang semangat masyarakat dalam menabung dan sekaligus sebagai indikator kesehatan bank. Insentif dalam perbankan adalah merupakan banking policy dalam upaya merangsang minat masyarakat terhadap bank, sekaligus sebagai indikator bank terkait. Karena semakin besar keuntungan nasabah semakin efisien pula pemanfaatan dana tersebut dalam investasi yang produktif dan menguntungkan. Tetapi dewasa ini, bukan tidak mungkin kalau bank mengombinasikan prinsip wadi'ah dengan prinsip mudharabah. Akibatnya, bank dapat menetapkan besaran bonus yang diterima oleh penitip, wajar saja ketika wadi'ah dianggap sebagai produk yang berpotensi mendapat keuntungan besar bagi pihak bank pada 
khususnya, walaupun tidak menutup kemungkinan juga resiko tetap menanti. Konsekuensi dari penggunaan prinsip ini adalah ketiadaan sistem bagi hasil dari bank untuk nasabah. Bank berhak atas keuntungan yang diperoleh dari pemanfaatan harta titipan tersebut dalam kegiatan-kegiatan komersial dan bukan merupakan unsur keuntungan yang harus dibagikan.

\section{METODE PENELITIAN}

Jenis penelitian ini adalah kualitatif-deskriptif. Oleh sebab itu, lebih memusatkan diri pada pemecahan masalah-masalah yang aktual kemudian data dikumpulkan, disusun, dijelaskan, dan kemudian dianalisis. Metode ini menggunakan analisis mendalam (in depth analysis), yaitu mengkaji masalah secara kasus perkasus karena metodologi kualitatif yakni bahwa sifat satu masalah akan berbeda dengan masalah lainnya. Metode ini berfungsi memberikan kategori substansif dan hipotesis penelitian kualitatif. Dalam penelitian ini yang dilakukan adalah melalui pendekatan kualitatif. Artinya data yang dikumpulkan bukan berupa angka-angka, melainkan data tersebut berasal dari naskah wawancara, dokumen pribadi, dan dokumen resmi lainnya (Moleong, 2004:131)

Teknik pengumpulan data yang akan dilakukan dalam penelitian ini adalah observasi, wawancara, dan dokumentasi. Analisis data adalah upaya yang dilakukan dengan jalan bekerja dengan data, mengorganisasikan data, memilah-milahnya menjadi satuan yang dapat dikelola, mensistensiskannya, mencari dan menemukan pola, menemukan apa yang penting dan apa yang dipelajari dan memutuskan apa yang dapat diceritakan kepada orang lain (Moleong, 2004:133). Data-data yang telah diperoleh dari observasi dan wawancara terhadap objek penelitian, diperoleh materi-materi yang kemudian diteliti, dianalisis, dikembangkan dan disesuaikan dengan teori-teori pendukung yang ada. Hasilnya adalah gambaran secara tertulis dari topik yang di angkat peneliti.

\section{HASIL DAN PEMBAHASAN}

Secara istilah, wadi'ah berarti mewakilkan penjagaan suatu harta yang spesial atau bernilai tertentu dengan cara tertentu. Akad wadi'ah merupakan suatu akad yang bersifat tolong-menolong antar sesama manusia yaitu tolong-menolong dalam hal menyempurnakan amanat (Afif, 
2016: 252). Wadi'ah dapat pula berarti titipan murni dari satu pihak ke pihak lain, baik individu maupun badan hukum yang harus dijaga dan dikembalikan kapan saja si penitip menghendakinya (Muhammad, 2001:85). Wadi'ah adalah akad seseorang kepada pihak lain dengan menitipkan suatu barang untuk dijaga secara layak (menurut kebiasaan). Akad pola wadi'ah (titipan) ada dua yaitu wadi'ah yad amanah dan wadi'ah yad dhamanah. Pada dasarnya wadi'ah muncul dalam bentuk yad amanah (tangan amanah) yang kemudian dalam perkembangannya memunculkan yad dhamanah (tangan penanggung), akad yad dhamanah ini akhirnya banyak yang dipergunakan dalam aplikasi perbankan syariah dalam produk pendanaan.

Ulama sepakat bahwa konsep wadiah berdasarkan prinsip kepercayaan (yad adl-amanah). Artinya, ketika asset titipan mengalami kerusakan yang disebabkan bukan karena kelalaian penerima titipan, maka tidak berkewajiban untuk menggantinya. Berbeda bila ceroboh, maka bertanggung jawab untuk mengganti. Selain itu, penerima titipan berkewajiban mengembalikan asset dengan segera, ketika penitip memintanya. Asset itu harus diserahkan kepada diri pribadi penitip, bukan orang lain. Jika asset diserahkan kepada orang lain, baik keluarga atau kerabat penting, kemudia terjadi kerusakan, penerima titipan harus menggantinya. (Dimyauddin, 2008: 175-176). Secara umum terdapat dua jenis wadi'ah yakni wadiah yad al amanah dan wadiah yad al dhammanah. Konsep wadi'ah yad al-amanah, pihak yang menerima titipan tidak boleh menggunakan dan memanfaatkan uang atau barang yang dititipkan. Pihak penerima titipan dapat membebankan biaya kepada penitip sebagai biaya penitipan. Sementara, konsep wadi'ah yad adh-dhamanah yaitu yang menerima titipan boleh menggunakan dan memanfaatkan uang atau barang yang dititipkan. Tentu, pihak bank dalam hal ini mendapatkan hasil dari penggunaan dana. Bank dapat memberikan insentif kepada penitip dalam bentuk bonus.

Bank syariah merupakan merupakan lembaga keuangan syariah yang memiliki fungsi menghimpun dana, mengelola dana, dan menyalurkan dana. Oleh karena itu bank syariah membutuhkan sumber-sumber dana yang akan dikelola. Dalam melakukan kegiatannya tersebut diperlukan produk-produk yang bisa menarik minat nasabah. BRI Syariah Kantor Cabang Purwokerto juga mempunyai produk-produk unggulan yang 
tentunya dilaksanakan sesuai dengan prinsip syariat Islam. Adapun produk-produk yang ada di BRI Syariah Kantor Cabang Purwokerto:

1. Produk penghimpunan dana. Produk penghimpun dana di BRI Syariah Kantor Cabang Purwokerto memberikan kemudahan masyarakan dalam melakukan transaksi seperti dalam bentuk tabungan, deposito, dan giro. Sementara produk tersebut meliputi : tabungan wadiah (tabungan Faedah BRI Syariah iB dan Simpanan Pelajar atau sumpel), tabungan murabahah (Tabungan Impian BRI Syariah iB, Tabungan Haji BRI Syariah iB, dan Tabungan Mikro), deposito mudharabah (Deposito BRI Syariah iB), dan giro mudharabah (Giro Faedah Mudharabah BRI Syariah iB).

2. Produk pembiayaan. Dalam produk pembiayaan di BRI Syariah meliputi: KPR Faedah BRI Syariah iB, KPR Sejahtera BRI Syariah iB, KKB BRI Syariah iB, Pembiayaan Umrah BRI Syariah iB, Kepemilikan Multifaedah Purna BRI Syariah iB, Kepemilikan Multifaedah Pra Purna BRI Syariah iB, Pembiayaan Kepemilikan Multi Faedah BRI Syariah iB, Pembiayaan Kepemilikan Emas BRI Syariah iB, Qardh Beragun Emas BRI Syariah iB, dam Pembiayaan Mikro BRI Syariah iB.

3. Produk jasa layanan. Dalam produk layanan ini meliputi : Mobile BRI Syariah, SMS BRI Syariah, Laku Pandai, Call Center BRI Syariah

BRI Syariah menerapkan akad wadi'ah pada produk tabungannya menggunakan akad wadi'ah yad dhamanah. Hal ini karena pihak BRI Syariah boleh memanfaatkan barang yang dititipkan oleh nasabah, dalam hal ini tentu bank mendapatkan hasil dari penggunaan dana titipan, dari hasil penggunaan dana tersebut pihak bank BRI Syariah dapat memanfaatkannya untuk kebutuhan di kantor BRI Syariah dan para pegawainya yang lainnya, namum BRI Syariah akan memberikan bonus secara sukarela kepada nasabah yang memenuhi syarat-syarat tertentu yang telah ditetapkan oleh BRI Syariah. Sedangkan jika menggunakan akad wadi'ah yad amanah pihak BRI Syariah sebagai pihak yang menerima titipan tidak boleh menggunakan dan memanfaatkan dana yang dititipkan oleh nasabah, hanya saja pihak bank dapat membebankan biaya kepada nasabah sebagai biaya penitipan.

Produk penghimpunan dana di BRI Syariah Kantor Cabang 
Purwokerto yang menggunakan akad wadi'ah yad dhamanah ada dua yaitu Tabungan Faedah BRI Syariah iB dan Tabungan Siswa. Tabungan Faedah (Fasilitas Serba Mudah) adalah produk simpanan dari BRI Unit Syariah ditujukan untuk simpanan harian perorangan dengan prinsip sesuai syariat Islam menggunakan akad Wadi'ah yad dhamanah. Meskipun pengelolaannya berdasarkan syariat Islam namun bersifat universal, semua golongan agama dapat membuka rekening Faedah. Nasabah tabungan Faedah di BRI Syariah dapat bertransaksi di seluruh jaringan kantor dan elektronik BRI Syariah secara online dan realtime. Dengan kartu ATM BRISyariah juga memudahkan melakukan beragam transaksi perbankan di ATM BRI Syariah serta di puluhan ribu jaringan ATM BRI, ATM Bersama maupun ATM Prima di seluruh Indonesia. Berbagai layanan perbankan yang dapat dilakukan melalui mesin ATM BRI Syariah antara lain, informasi saldo, tarik tunai, ganti pin, transfer ke rekening BRI Syariah maupun ke bank lain, pembiayaan tagihan : telkom PSTN, telkomvision, internet speedy, telco pascabayar (flexy, kartu HALO, XL, AXIS, ESIA, Smartfren), PLN (pascabayar, non tagihan listrik). Kartu ATM BRISyariah juga berfungsi sebagai kartu debit untuk berbelanja tanpa menggunakan uang tunai di seluruh merchant berlogo Debit BRI dan Prima. Karena tabungan ini jenis tabungan harian, maka transaksi tidak terikat jangka waktu, jumlah penyetoran dan penarikannya bisa dilakukan kapan saja. Tabungan Faedah BRI Syariah termasuk simpanan yang diikutsertakan dalam program penjaminan pemerintah sehingga memberikan ketenangan dan kenyamanan bagi nasabah apabila pihak bank syariah mengalami kebangkrutan. Adapun syarat dan ketentuan pembukaa rekening tabungan Faedah yaitu membawa fotocopy KTP yang masih berlaku, fotocopy NPWP bagi yang mempunyai.

Tabungan Siswa atau Simpanan Pelajar (SimPel) BRI Syariah iB adalah tabungan untuk siswa yang diterbitkan secara nasional oleh bank-bank di Indonesia dengan persyaratan mudah dan sederhana serta fitur yang menarik, dalam rangka edukasi dan inklusi keuangan untuk mendorong budaya menabung sejak dini. Simpanan Pelajar (SimPel) bermanfaat bagi siswa karena memberikan edukasi keuangan pada siswa, mendorong budaya menabung sejak dini, melatih pengelolaan keuangan sejak dini. Bagi orang tua bermanfaat memberi edukasi tentang produk 
tabungan, mengajarkan kemandirian anak dalam mengelola keuangan, memudahkan orang tua untuk mengontrol pengeluaran anak. Sedangkan bagi sekolah memberikan manfaat sebagai sarana edukasi praktis keuangan dan perbankan bagi siswa dan guru, menumbuhkan budaya menabung di sekolah, sarana sistem pembayaran dan pengelolaan keuangan yang efektif dan efisien di lingkungan sekolah. Adapun persyaratannya ada perjanjian kerja sama antara BRI Syariah dengan sekolah, mengisi kelengkapan Aplikasi Pembukaan Simpel iB, melengkapi dokumen pembukaan rekening untuk siswa menggunakan Kartu Keluarga/NISN/NIS sedangkan untuk orang tua menggunakan KTP. Fitur dan biaya yang dikenakan BRI Syariah (www.brisyariah.co.id) adalah :

1. Setoran awal minimum Rp. 1000,-

2. Setoran selanjutnya minimum Rp. 1000,-

3. Saldo mengendap minimum Rp. 1000,-

4. Limit penarikan Rp. 500.000,-/hari

5. Dapat diberikan kartu ATM (optional)

6. Dapat diberikan fasilitas e-channel berupa MobileBRIS, SMSBRIS, dan phone phone banking (CallBRIS)

7. Biaya administrasi tabungan : GRATIS

8. Biaya saldo mengendap dibawah minimum : GRATIS

9. Biaya rekening dormant Rp. 1000,-/bulan (dikenakan apabila rekening tidak aktif transaksi selama 12 bulan)

10. Biaya penggantian buku tabungan saat pembukaan rekening atau karena habis : GRATIS

11. Biaya penggantian buku tabungan karena hilang/rusak Rp. 5000,-

12. Biaya pembuatan kartu ATM Rp. 5000,-

13. Biaya penggantian kartu ATM karena rusak/hilang Rp 15.000,-

14. Biaya penutupan rekening Rp 1.000,-

Dari kedua tabungan yang menggunakan akad wadi'ah di BRI Syariah yang paling banyak diminati oleh nasabah adalah tabungan Faedah karena tertuju untuk semua kalangan yang sudah memiliki KTP, setoran awal ringan yaitu Rp. 100.000,-, saldo mengendap sebesar Rp. 50.000. Bagi nasabah tabungan Faedah BRI Syariah iB maupun nasabah tabungan SimPel, pihak BRI Syariah akan memberikan bonus bagi nasabahnya yang 
memenuhi kriteria tertentu sesuai ketentuan yang ditetapkan BRI Syariah, pemberian bonus tersebut tidaklah diperjanjikan di awal melakukan akad akan tetapi diberikan secara sukarela oleh pihak BRI Syariah. Adapun keunggulan dari tabungan yang menggunakan akad wadi'ah yad dhamanah dengan akad tabungan yang menggunkan akad mudharabah.

1. Simpanan dapat diambil kapan saja, tabungan yang menggunakan akad wadi'ah sesuai bagi nasabah yang mengutamakan keamanan dana dan kemudahan transaksi sehari-hari.

2. Dapat dijadikan simpanan untuk masa depan.

3. Meskipun tidak ada bagi hasil, namun pihak bank syariah dapat memberikan bonus secara sukarela kepada nasabah yang memenuhi syarat-syarat yang diterapkan pihak bank

Penerapan akad wadi'ah pada produk tabungan di BRI Syariah Kantor Cabang Purwokerto yaitu, nasabah BRI Syariah yang akan membuka tabungan yang menggunakan akad wadi'ah yad dhamanah untuk tabungan Faedah BRI Syariah iB pertama-tama yaitu nasabah memberikan KTP Elektronik dan NPWP jika sudah punya kepada costumer service untuk dilihat datanya yang sudah terhubung ke Dukcapil setempat. Calon nasabah kemudian diminta untuk mengisi formulir pendaftaran secara lengkap yang terdiri dari 4-5 lembar, setelah selesai mengisi formulir pendaftaran calon nasabah diminta membaca Akad Wadi'ah Yad Ad Dhamanah tabungan Faedah BRI Syariah iB yang sudah tertulis dalam formulir pembukaan tabungan, kemudian menandatangani akad tersebut. Costumer service menjelaskan akad wadi'ah yad dhamanah pada saat nasabah sedang mengisi formulir pembukaan rekening. Kemudian nasabah diminta membalik kertas formulir pembukaan tabungan dan membaca Syarat dan Ketentuan Umum Tabungan Faedah BRI Syraiah iB kemudian membubuhkan tanda tangan dibagian kanan bawah. Costumer Service akan memeriksa data yang telah ditulis oleh nasabah dan menambahkan tanda tangan pada formulir pembukaan tabungan dihalaman awal di sebelah kiri bawah. Setoran awal yang harus dibayar nasabah adalah Rp. 100,000.- dan saldo mengendap dalam tabungan tersebut adalah sebesar Rp. 50.000, biaya administrasi bulanan sebesar Rp. 0, serta gratis biaya atm bulanan.

Penarikan dana nasabah dapat dilakukan sewaktu-waktu kapanpun 
nasabah membutuhkan dengan cara tarik tunai diseluruh jaringan ATM BRI, Bersama dan Prima. Apabila nasabah mengisi saldo awal lebih dari Rp. $500.000,00$ maka nasabah tersebut hanya dikenakan biaya 50\% dari biaya normal. Misalnya biaya transfer yang seharusnya Rp. 6.500,00 menjadi hanya Rp. 3.250,00. Fasilitas yang diberikan antara lain saat membuka rekening akan mendapatkan kartu ATM, mobile banking.

Bagi nasabah yang ingin menutup rekening tabungan yang menggunakan akad wadi'ah maka prosedurnya adalah yang pertama nasabah datang ke BRI Syariah Kantor Cabang Purwokerto tempat pertama kali membuat rekening atau ke kantor cabang lain sesuai dengan syarat dan ketentuan yang berlaku, dengan membawa buku tabungan, kartu ATM dan KTP Elektronik dan menyerahkan kepada customer service kemudian nasabah akan diminta untuk mengisi kertas berisi permohonan penutupan rekening dan menandatanganinya serta menyerahkan kembali kepada customer service untuk di teliti lagi. Setelah itu customer service akan meminta nasabah untuk menunggu antrian di teller guna mengambil dana yang tersisa di dalam tabungan. Biaya penutupan rekening sendiri adalah sebesar Rp. 25.000. Penutupan rekening tabungan yang menggunakan akad wadi'ah hanya dapat dilakukan apabila para pihak sepakat mengakhiri akad, nasabah meninggal dunia dan penutupannya hanya dapat dilakukan oleh ahli waris yang sah dengan melampirkan fatwa waris/keterangan waris/penetapan ahli waris dalam pembagian waris yang dikeluarkan oleh pihak yang berwenang, kemudian apabila nasabah melanggar ketentuan perundang-undangan yang berlaku dan/atau menyalahgunakan rekening tabungan untuk sesuatu yang tidak sesuai syariah, hal ini dilakukan oleh bank dengan memberitahu kepada nasabah dan sesuai dengan tata cara yang berlaku pada bank.

Pembukaan tabungan SimPel (Simpanan Pelajar) sama seperti pembukaan tabungan Faedah namun harus ada kerjasama dahulu antara BRISyariah dan Sekolah, setelah ada kerjasama kemudian siswa diminta mengisi kelengkapan Aplikasi Pembukaan Rekening. Biaya setoran awal minimum yaitu hanya Rp. 1000, dan saldo mengendap minimum Rp. 1000,-. Setelah itu akan memperoleh buku tabungan dan memperoleh kartu ATM (optional). Tabungan SimPel (Simpanan Pelajar) juga dapat diberikan binus sesuai dengan kebijakan bank. Rekeningnya dapat diberikan layanan 
autodebet berdasarkan standing instruction, pembayaran tagihan rutin, zakat/infaq/sedekah, autosweep dan sebagainya. Sementara itu biaya untuk penutupan rekening tergolong murah yaitu sebesar Rp. 1000,- Adapun permasalahan yang umum terjadi mengelola akad wadi'ah di BRI Syariah sendiri terdapat jeda transaksi pada jam 22:00 sampai 22:30 malam karena dilakukan rekap, saat terjadi rekap biasanya akan mengalami gangguan seperti ATM offline, mobile BRI Syariah offline. Bagi calon nasabah yang akan membuka rekening tabungan Faedah BRI Syariah iB dan baru mempunyai KTP Elektronik dan akan membuka tabungan menggunakan akad wadi'ah biasanya akan mengalami masalah saat pihak custumer service mengakses data pribadinya, berupa data yang tidak valid atau tidak muncul saat di akses kemudian nasabah akan diminta mengecek ulang perekaman di Dukcapil untuk mengetahui datanya sudah diuplod ke sistem integrasi secara nasional atau belum.

Tabungan wadi'ah merupakan produk bank syariah yang berupa simpanan dalam bentuk rekening tabungan, yang memberikan keamanan bagi nasabah dan simpanan tersebut dapat di ambil kapan saja. Tabungan yang menggunakan akad wadi'ah di BRI Syariah Kantor Cabang Purwokerto di aplikasikan dalam produk tabungan Faedah BRI Syariah iB dan Tabungan SimPel BRI Syariah iB. Bank BRI Syariah meluncurkan produk Tabungan Faedah BRI Syariah iB dan tabungan SimPel BRI Syariah iB sebagai salah satu wujud pelayanan terhadap masyarakat yang menginginkan kemudahan dalam transaksi keuangan, tabungan ini merupakan simpanan harian perorangan yang dapat diambil kapan saja, menggunakan akad wadi'ah yad dhamanah, dimana pihak bank BRI Syariah dapat memanfaatkan dana yang dititipkan oleh nasabah. Pemilihan akad wadi'ah yad dhamanah dari pada akad wadi'ah yad amanah dikarenakan akad wadi'ah yad dhamanah merupakan akad yang ideal untuk diterapkan perbankan syariah mengingat pihak bank syariah merupakan bank yang menghindari unsur riba disisi lain bank syariah membutuhkan dana untuk perkembangan produknya dan lain lain. Tabungan wadi'ah juga bukan tabungan yang bersifat investasi, dengan demikian tabungan Faedah BRI Syariah iB dan Tabungan SimPel dapat diberikan fasilitas buku tabungan dan kartu ATM agar nasabah dapat menarik dananya kapan saja, karena bersifat simpanan/titipan hal ini bisa digunakan nasabah yang ingin 
menyimpan dananya untuk masa depan, meskipun tidak ada bagi hasil seperti dalam akad mudharabah namun pihak bank syariah dapat memberikan bonus secara sukarela kepada nasabah yang memenuhi syarat-syarat tertentu yang sudah diterapkan pihak bank syariah.

Adapun pengelolaan tabungan yang menggunakan akad wadi'ah di BRI Syariah Kantor Cabang Purwokerto mengacu pada ketentuan fatwa NO:02/DSN-MUI/IV/2000 tentang tabungan wadi'ah, yaitu pada produk tabungan Faedah BRI Syariah iB dan Tabungan SimPel BRI Syariah iB, dengan berlandaskan pada :

1. Bersifat Simpanan

Nasabah BRI Syariah Kantor Cabang Purwokerto yang menginginkan kemudahan keuangan sehari-hari menitipkan dana dengan memilih jenis tabungan yang dikehendaki Tabungan Faedah BRI Syariah iB untuk yang sudah berusia 17 tahun dan memiliki KTP Elektronik dan tabungan SimPel (Simpana Pelajar) bagi anak-anak yang masih sekolah, pembukaan tabungan untuk anak sekolah dilakukan atas kerjasama antara bank dan sekolah terlebih dahulu. Kemudian pihak bank akan bersedia menerima penitipan. Melihat akad yang digunakan adalah wadi'ah yad dhamanah maka dengan diterimanya dana titipan pihak bank dapat mengelola dana dari nasabah yang di administrasikan dalam bentuk rekening Tabungan Faedah BRISyariah iB atas nama nasabah pada bank, selain itu nasabah wajib mematuhi semua peraturan dan ketentuan yang ditetapkan oleh pihak bank sebagaimana telah tertera dalam Formulir Pembukaan Tabungan dan ditanda tangani oleh nasabah. Dengan ditanda tanganinya Formulir tersebut nasabah berarti siap mematuhi ketentuan umum yang dibuat pihak bank. Hal ini dikarenakan syarat dan ketentuan umum tabungan yang menggunakan akad wadi'ah merupakan bagian yang tidak terpisahkan dari Aplikasi Permohonan Pembukaan Rekening Tabungan dan akad antara Bank dan Nasabah yang tertera dibalik halaman. Syarat dan ketentuan khusus tabungan menggunakan akad wadi'ah serta Customer Informasi File (CIF).

2. Simpanan bisa diambil kapan saja (on call) atau berdasarkan kesepakatan. 
Tabungan Faedah BRI Syariah iB dan Tabungan SimPel BRI Syariah iB merupakan jenis simpanan yang dipersembahkan untuk nasabah yang menginginkan kemudahan dalam bertransaksi keuangan. Sehingga penarikan uangnya di bisa dilakukan kapan saja sesuai keinginan nasabah. Dengan fasilitas adanya kartu ATM BRI Syariah nasabah bisa melakukan beragam transaksi perbankan di ATM BRI Syariah serta dipuluhan ribu jaringan ATM BRI, ATM Bersama maupun ATM Prima di seluruh Indonesia. Hal ini juga sesuai dengan Akad Wadi'ah Yad Ad Dhamanah Tabungan Faedah BRISyariah iB point ke 4 yang berbunyi, "Dana yang terdapat pada rekening nasabah dapat diambil/ditarik oleh nasabah setiap saat baik sebagian atau seluruhnya dan bank menjamin pengembalian dana nasabah hal tersebut sesuai dengan ketentuan yang berlaku."

3. Tidak ada imbalan yang disyaratkan, kecuali dalam bentuk pemberian ('athaya) yang bersifat sukarela dari pihak bank.

Kebijakan yang diterapkan di BRI Syariah Kantor Cabang Purwokerto yaitu pihak bank tidak mensyaratkan bonus pada saat pembukaan rekening tabungan yang menggunakan akad wadi'ah. Pada saat pembukaan rekening tabungan yang mengguanakan akad wadi'ah, nasabah hanya diarahkan untuk mengisi formulir pembukaan tabungan yang terdiri dari sekitar 5 lembar, setelah itu nasabah akan diminta membaca Akad Wadi'ah Yad Dhamanah yang sudah tertulis di bagian bawah formulir pembukaan rekening. Jika nasabah setuju, akan diminta untuk menanda tangani dibagian kiri bawah. Kemudian akan diminta membaca Ketentuan Umum Tabungan dan menanda tangani di bagian kanan bawah. Costumer service akan memeriksa data yang telah diisi oleh nasabah.

Sesuai dengan fatwa DSN MUI, dan dengan memperhatikan ketentuan yang berlaku megenai akad wadi'ah yad dhamanah, BRI Syariah dapat memberikan bonus atau hadiah kepada nasabah, namum pemberian bonus itu dilakukan secara sukarela oleh pihak BRI Syariah, hanya diberikan kepada nasabah yang memenuhi syarat-syarat yang ditetapkan pihak BRI Syariah. Adapun ketentuan nasabah yang mendapatkan bonus adalah apabila saldo rata-rata dalam satu bulan dijumlah minimal 1 juta, 
apabila mencapai 1 juta maka pihak BRI Syariah dapat memberikan bonus kepada nasabah. Pajak atas bonus yang diterima nasabah ditanggung oleh nasabah sendiri dan dipotong langsung dari pendapatan bonus yang diterimanya. Besaran pemberian bonus setiap bulan dicantumkan di papan depan pelayanan costumer service di BRI Syariah Kantor Cabang Purwokerto. Oleh sebab itu, pengelolaan dana pada produk tabungan yang menggunakan akad wadi'ah di BRI Syariah Kantor Cabang Purwokerto juga telah sesuai dengan ayat-ayat alqur'an dan hadits yang menjadi rujukan wadi'ah, diantaranya adalah:

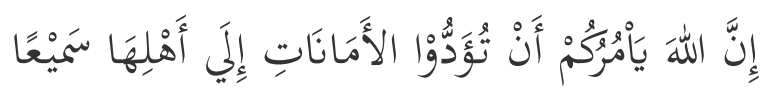

"Sesungguhnya Allah menyuruh kamu untuk menyampaikan amanat (titipan) kepada yang berhak menerimanya (QS. An- Nissa ayat 58)

Berdasarkan ayat tersebut menerangkan bahwa barang titipan harus dikembalikan kepada pemiliknya disaat pemilik harta titipan memintanya dan penerima titipan wajib mengembalikan amanat tersebut tepat waktu atau sesuai dengan kesepakatan oleh keduanya. Penerapannya dalam BRI Syariah adalah nasabah dapat menarik dananya kapan saja sesuai kebutuhan, sedangkan pihak BRI Syariah dalam akad wadi'ah yad dhamanah meskipun memanfaatkan dana dari nasabah untuk kepentingan bank, namun pihak BRI Syariah siap mengembalikan dana nasabah kapanpun nasabah menginginkannya. Ayat kedua yang menjadi rujukan wadi'ah yaitu berdasarkan Q.S Al-Baqarah ayat 283 :

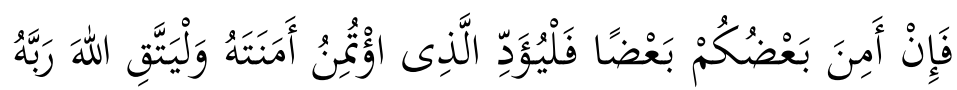

“.... jika sebagian kamu mempercayai sebagian yang lain, Maka hendaklah yang dipercayai itu menunaikan amanatnya (hutangnya) dan hendaklah ia bertakwa kepada Allah Tuhannya ...."

Berdasarkan ayat kedua diketahui bahwa apabila dalam melakukan akad wadi'ah, di antara kedua pihak haruslah saling mempercayai dan berbaik sangka, tidak adanya penghianatan atau mengingkari hak-hak dan kewajiban-kewajibannya. Dalam BRI Syariah Kantor Cabang Purwokerto sendiri yaitu pihak BRI Syariah sebagai penerima amanat atau titipan dana menjamin aman dana yang di titipkan oleh nasabah apabila suatu saat pihak pihak BRI Syariah mengalami kebangkrutan atau permasalahan yang 
lain, karena dana nasabah tersebut diikutsertakan dalam program penjaminan pemerintah. Sedangkan pihak nasabah diminta mematuhi ketentuan umum yang diterapkan oleh pihak BRI Syariah yang sudah tercantum dalam formulir pembukaan rekening, dengan di tanda tanganinya formulir pembukaan rekening menandakan bahwa nasabah setuju dan telah mengerti isi dari syarat dan ketentuan umum yang di buat oleh pihak BRI Syariah. Berdasarkan pada hadits Rasulullah SAW tentang wadi'ah. Abu Hurairoh meriwayatkan bahwa Rasulullah SAW bersabda :

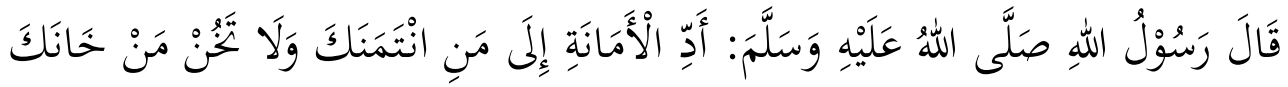
"Sampaikanlah (tunaikanlah) amanat kepada yang berhak menerimanya dan jangan membalas khianat kepada orang yang telah mengkhianatimu" (HR Abu Dawud dan menurut Tirmidzi hadits ini hasan, sedang Imam Hakim mengkategorikan sahih).

Berdasarkan hadist tersebut di atas, menerangkan bahwa pihak yang menerima titipan agar mengembalikan kepada yang mempunyai titipan, dan pihak yang merasa mampu dan sanggup menerima titipan adalah sangat baik dan mengandung nilai ibadah juga mendapat pahala, disamping mempunyai nilai social yang tinggi. Dalam BRI Syariah, pihak bank sanggup menerima titipan dana dari nasabah, dan bersedia mengembalikan titipan dana tersebut kapan saja. Pihak bank menjamin titipan dana dari nasabah, karena dana tersebut diikutsertakan dalam program penjaminan pemerintah. Akad pada produk tabungan Faedah BRI Syari'ah iB dan Tabungan SimPel sudah memenuhi rukun dan syarat dalam melakukan akad yaitu dengan adanya :

1. Adanya pemilik harta;penitip/muwaddi. Dimana dalam hal ini yang bertindak sebagai pemilik harta adalah nasabah.

2. Adanya penerima harta titipan. Yang bertindak sebagai penerima titipan adalah pihak bank syariah

3. Adanya harta yang dititipkan. Dalam penerapannya harta nasabah yang dititipkan berupa uang yang diaplikasikan dalam bentuk tabungan.

4. Adanya sighat (ijab qabul). Proses yang menunjukan adanya ijab qabul adalah pada saat nasabah mengisi formulir pembukaan rekening lalu membaca ketentuan umum yang diterapkan oleh pihak bank syariah 
dan kemudian apabila nasabah menyetujuinya maka costumer service akan meminta untuk menanda tanganinya.

\section{SIMPULAN}

Produk tabungan yang menggunakan akad wadi'ah yad dhamanah di Bank BRI Syariah Kantor Cabang Purwokerto ada dua macam produk, yaitu Tabungan Faedah BRI Syariah iB dan Tabungan SimPel (Simpanan Pelajar). Keduanya menggunakan akad wadi'ah yad dhamanah, dimana pihak bank dapat memanfaatkan dana yang dititipkan oleh nasabah, akan tetapi bank dapat memberikan bonus secara sukarela. Bahwa dalam proses menerapkan akad wadi'ah yad dhamanah pada produk tabungan di BRI Syariah Kantor Cabang Purwokerto sudah mempunyai dasar hukum yang kuat yaitu berpedoman pada fatwa DSN-MUI No: 02/DSN-MUI/IV/2000 tentang Tabungan, yang sudah diterapkan sejak pertama mendirikan BRISyariah. Akan tetapi pelayanan costumer servis dalam melayani nasabah yang akan membuka rekening tabungan yang masih mengalami kesalahan, dan kurang ideal. Tabungan Faedah BRI Syariah iB dan Tabungan SimPel di BRI Syariah Kantor Cabang Purwokerto merupakan simpanan yang memudahkan masyarakat serta sudah memiliki dasar hukum dan sesuai dengan Fatwa Dewan Syariah Nasional Majelis Ulama Indonesia, hanya saja pelayanan untuk nasabah yang kadang mengalami kesalahan hal itu terjadi karena banyak pegawai BRI Syariah yang bukan berasal dari lulusan hukum ekonomi syariah atau sejenisnya.

\section{DAFTAR REFERENSI}

A, Karim, Adiwarman. 2011. Bank Islam: Analisis Fiqih dan Keuangan. Jakarta: Rajawali Press.

Antonio, Muhammad. S. (2001). Bank Syariah: Dari Teori ke Praktik. Jakarta : Gema Insani.

Djuwaini, Dimyauddin. 2008. Pengantar Fiqh Muamalah. Yogyakarta: Pustaka Pelajar.

Lewis, Mervvyn. Latifah Algaoud. (2001). Perbankan Syariah: Prinsip, Praktik, dan Prospek. Jakarta: PT. Serambi Ilmu Semesta

Meleong, lexy J. (2007). Metode Penelitian Kualitatif. Bandung: Remaja Rosda Karya.

Mujahidin, A. (2016). Hukum Perbankan Syariah. Jakarta: PT. Rajagrafindo Persada. 
Muhammad. Dwi Suwiknyo. 2009. Akuntansi Perbankan Syariah. Yogyakarta: Trust Media

Makhrus, M. "Peran Perguruan Tinggi dalam Mendorong Pengembangan Sumber Daya Insani pada Lembaga Keuangan Syariah." ISLAMADINA (2015): 52-66.

Santori, Djam'an. (2011). Metodologi Penelitian Kualitatif. Bandung: CV. Alfabeta

Shohin, Ahmad Ifham. 2010. Pedoman Umum Lembaga Keuangan Syariah. Jakarta: PT. Gramedia Pustaka Utama.

Soemitra, Andri. 2009. Bank dan Lembaga Keuangan Syariah. Jakarta: Kencana Prenada Media Group.

Afif, Mufti. "Tabungan: Implementasi Akad Wadi'ah atau Qard? (Kajian Praktik Wadi'ah di Perbankan Indonesia). "Jurnal Hukum Islam IAIN Pekalongan, 2016.

Aisyah, Siti. "Penghimpunan Dana Masyarakat Dengan Akad Wadi'ah Dan Penerapannya Pada Perbankan Syariah." SYARI'AH: Jurnal Ekonomi Syari'ah5.1 (2016)

Alamsyah, H. (2012). Perkembangan dan Prospek Perbankan Syariah Indonesia: tantangan dalam menyongsong MEA 2015.

Anshori, A. G. (2008). Sejarah Perkembangan Hukum Perbankan Syariah di Indonesia dan Implikasinya bagi Praktik Perbankan Nasional. La_Riba, 2(2), 159-172.

Nugroho, B. W. W. (2013). Analisis Efisiensi Perbankan Menggunakan Metode Non Parametrik Data Envelopment Analysis (Dea). Jurnal Ilmu Manajemen (JIM), 1(1). (diakses pada tanggal 30 Juli 2018)

Riyanto, Yatim. (1996). Metode Penelitian Pendidikan Tinjauan Dasar. Surabaya: SIC

Widayatsari, A. (2013). Akad Wadiah dan Mudharabah dalam Penghimpunan Dana Pihak Ketiga Bank Syariah. Economic: Journal of Economic and Islamic Law, 3(1), 1-21.

Yulianti, R. T. (2008). Asas-Asas Perjanjian (Akad) dalam Hukum Kontrak Syari'ah.http://www.jurnal.uii.ac.id/index.php/JEI/article/download /164/129(diakses pada tanggal 22 Maret 2018)

http://www.brisyariah.co.id (diakses pada tanggal 1 April 2018)

http://www.ojk.go.id (diakses pada tanggal 5 April 2018) 